\title{
チャンディガール州都計画におけるル・コルビュジエの住宅構想に関する研究 一土着的な要素を取り入れた住宅設計一 \\ A STUDY ON LE CORBUSIER'S HOUSING CONCEPT \\ FOR THE URBAN PROJECT IN CHANDIGARH
}

Le Corbusier's housing design referring to vernacular elements

大野隆司*, 川向正人**

\section{Takashi OHNO and Masato KAWAMUKAI}

This study aims to clarify Le Corbusier's housing concept referring to vernacular elements. Particularly, this paper focuses on the housing composition in the urban project of Chandigarh. He investigated the vernacular housing in India and extracted nine elements: long narrow site, screens, bedroom, verandah, front garden, rear garden, orientation, roof form and fixtures (tip-up door and claustra). These elements were extracted from the traditional houses and villages to adapt to the climate of the region: strong sunlight, heat and humidity during the rainy season, southeast wind and heavy rainfall. The housing of Chandigarh presented by Le Corbusier inherits these vernacular elements.

Keywords : Le Corbusier, Chandigarh, Housing, Vernacular, Veranda, Climate ル・コルビュジエ, チャンディガール, 住宅, 土着, ベランダ, 天候

\section{1. はじめに}

本論は、ル・コルビュジエ（Le Corbusier，1887-1965）が土着 の要素を取り入れた住宅を設計していたことを解明する一連の研 究の一つである。とくにチャンディガール（Chandigarh）州都計 画に焦点を当て、土着的要素を取り入れた住宅構成の解明を目的と する。

1930 年代以降、ル・コルビュジェは地域的な要素に目を向けて いった。地域ごとの気候・環境・生活スタイルに適した住空間の構 成を彼は調查・分析し、建築設計に積極的に取り入れていく。

筆者はすでに、南米ボゴタで土着的な要素「クアドラ(cuadra)」 が低層住居街区計画に発展的に継承されていることを明らかにし ている湦1)。ほぼ同時期注 2)に計画されたチャンディガール州都計画 でも土着の要素を取り入れた計画手法が用いられていると考えら れる。だが、ル・コルビュジエが捉えたインドの土着的な要素に焦 点を当てた既往研究は見受けられない。

チャンディガールは、インド独立の象徵となる新都市を目指した、 新しいパンジャブ州の州都として計画された注3)。1950 年 12 月 19 日にル・コルビュジエは州政府と契約を交わし、「建築アドバイザ 一 (Architectural Adviser)」に就任した注4)。彼の指揮の下、3人 の協働者や現地の建築家とともに新州都計画が進められている。

就任直後に、ル・コルビュジエは現地調查を行った。チャンディ ガールの住宅計画は本来、協働者たちに任せられていたはずだった
が、ル・コルビュジエは現地調査後すぐに独自の計画案を強引に提 示した注5)。

チャンディガールでル・コルビュジエが計画した住宅は一種類の みで、「110 $\mathrm{m}^{2} の$ 廉価住宅(logis de $\left.110 \mathrm{~m}^{2}\right) 」$ と命名されている。こ の住宅は $110 \mathrm{~m}^{2}$ の敷地に建つ、低所得労働者用のローコスト住宅で ある(注の。計画期間は建築アドバイザー就任直後から約 2 年間であっ た。この間に彼は現地訪問を 2 回しているが、初回の調查でほぼ計 画案の骨子が決定している。

$110 \mathrm{~m}^{2}$ の廉価住宅の計画は、実現には至っていない注7。だが、協 働者たちが計画したチャンディガールの住宅を精緻に調查して一 冊に纒めたキラン・ジョシ著"Documenting Chandigarh"を見ると、 実現した計画にル・コルビュジエの案が強く影響していることが分 かる注8)。また、ル・コルビュジエがアーメダバードに計画したサラ バイ邸 (Villa Sarabhai, 1951) やチマンバイ邸(Villa Chimanbhai) で用いられる住空間の構成にも、110 $\mathrm{m}^{2} の$ 廉価住宅との関係が伺え る注9)。

この住宅の設計に際してル・コルビュジエは協働者について「現 地の気候・環境も考慮せずに、西欧のアプローチをとる傾向がある 注 10)」と述べて、既存の設計手法の見直しを求めていた。そのため、 彼自身の設計案には現地の気候や環境への配慮が反映されている と考えられる。

本論は、次の構成をとる。まず、ル・コルビュジエが現地調查で
* 東京理科大学大学院理工学研究科 博士後期課程 $\cdot$ 工修

** 東京理科大学理工学部建築学科 教授. 工博
Graduate Student, Dept. of Architecture, Tokyo Univ. of Science, M. Eng. Prof., Dept. of Architecture, Faculty of Science and Technology, Tokyo Univ. of Science, Dr. Eng. 
描いた土着の住宅や集落のスケッチとそれに添えられたメモから、 彼が注目した土着の住宅の要素を抽出し、インドでの住宅設計に際 して重視すべき条件をどのように捉えていたかを明らかにする。次 に、 $110 \mathrm{~m}^{2}$ の廉価住宅の計画図面の変遷を詳細に分析して、彼が土 着の住宅から見出した設計条件を実際の計画にどのように反映さ せていったのかを解明する。

研究資料には、ル・コルビュジエ財団 (Fondation Le Corbusier) に所蔵された書簡、スケッチ、図面を用いている注 11 。 とくに、彼 が注目した土着の要素を抽出するためには、初回調查で描かれた 《Album punjab, simla, chandigarh》》注12)を含む、《Carnet nivola 1》 注 13) 、 《Ahmedabad, Février 1951, 1951 India, $1^{\mathrm{er}}$ carnet, Ronchamp》 注 ${ }^{14)}$ の 3 冊のスケッチブックを参照した。《Album punjab, simla, chandigarh》は未だ出版されておらず、その内容は ほとんど知られていないが、このスケッチブックには都市計画案の 骨子のほかに、土着的な住宅の生活が詳細に描かれている。

\section{2.ル・コルビュジエによる土着的な住宅の調査}

\section{2-1. 調査経緯}

チャンディガール州都計画は 1948 年からスタートしていたが、 ル・コルビュジエが計画に携わる意思を表明したのは、 50 年 12 月 6 日パリで行われたミーティングのときであった注15)。彼は計画参画 への意思表明と同時に、この計画の第一歩として、インドへの理解 を深めるために現地調查を行うこと、その経験をもとに先任者アル バート・マイヤー(Albert Mayer, 1897-1981)が作成した都市プラン を修正することを明言した。

\section{2-2. 現地調査（第 1 回インド訪問 1951 年 2 月 21 日-1951 年 4 月 1 日}

1951 年 2 月、ル・コルビュジエは初めてインドを訪れた注 ${ }^{16}$ 。 初回の調查期間は、約 1 ケ月半である。訪問先は大きく 2 つに分 かれる。まず $1 つ$ 目は、インド北部のシムラ、チャンディガールと それらの周辺で、約 1 ケ月間。もう 1 つはデリー、アーメダバード、 ボンベイなど主要都市で、約半月間注17)。
この調査で、ル・コルビュジエのスケッチブックに描かれた土着 の住宅に関する調查記録を一覧表にすると、表 1 の通りである。

表 1 では、ル・コルビュジエ財団の保管資料を表す略記 FLC と その整理番号（W1-2、W1-5、W1-8）で示している。日付が明記さ れている場合はそれを記載している。明記されていない場合でも、 前後に書かれたスケッチの日付や記録内容から、いつ、どこで描か れたものかはある程度、推定できる。

ル・コルビュジエがこの現地調査でいかなる土着的要素に着目する ようになったかは、次章で住宅の構成要素に分けて具体的に説明寸 るが、調查記録全体を概観すると、この土地で快適な生活を送るに は、気候、とくに降水量が多く高温多湿でもある雨期に適合した住 宅を設計すべきだと、彼が考えていたことが分かる。なかでも彼が 重要と捉えるのは、雨期に吹く地域特有の南東風の利用である。

そのためにル・コルビュジエは、細長い短冊状の敷地割、住宅本 体の前後に置かれた広い庭、どんな天候でも室内を開放できるほど 深い軒を有するべランダ、街路と前庭を隔てる塀の存在、高温多湿 な室内の空気を排除するための住宅断面形状（屋根形状）、そして、 室内を開放したり、閉じていても風を通したりできる間仕切り（建 具）などの土着的要素に着目したようである。全体として、開放的 な室内環境の確保に重点が置かれているように感じられる注18)

\section{3.ル・コルビュジェが注目した土着の要素}

表 1 のル・コルビュジエのスケッチやそこに記されたメモからは、 住宅の構成要素が 9 つ抽出できる。「短冊状敷地」「前庭」「塀」「裏 庭」「寝室」「ベランダ」「方位」「屋根形状」「建具」である。表 1 に挙げたスケッチのうち、これらの要素が分かりやすく表れている 代表的な例を取り上げて分析する。

\section{3-1. 住宅と庭との関係}

ル・コルビュジエは、アーメダバードからボンベイに向かう機内 から地上を見下ろして、図 1 ・図 2 を描いている。図 1 はボンベイ 空港近くの労働者の村落で注 19)、1 枚に 2 つのスケッチが描かれてい
表 1 ル・コルビュジエの土着の住宅に関連するスケッチとそこに描かれた要素

\begin{tabular}{|c|c|c|c|c|}
\hline FLC & 頁 & 日付 & 内容 & 要素 \\
\hline W1-2 & 400 & - & ボンベイ空港近くの労働者の「村落」（図 1、2) & $\mathrm{A}, \mathrm{B}, \mathrm{C}, \mathrm{D}$ \\
\hline \multirow{12}{*}{ W1-5 } & 5 & - & 土着の既存住宅（外観と平面）、片流れ屋根（図 7) & $\mathrm{H}$ \\
\hline & 14 & - & ベランダの記述 & $\mathrm{F}$ \\
\hline & 17 & 1951.2 .23 & 既存の住宅、片流れ屋根 & $\mathrm{H}, \mathrm{F}$ \\
\hline & 18 & 1951.2 .23 & 季節ごとの住宅での生活（図 6) & $\mathrm{F}, \mathrm{G}$ \\
\hline & 19 & 1951.2 .25 & 住宅の平面構成とその特徵（図 3) & $\mathrm{D}, \mathrm{E}, \mathrm{F}$ \\
\hline & 20 & 1951.2 .25 & 寝室の構成（図 5) & $\mathrm{E}$ \\
\hline & 30 & - & 既存の住宅（勾配屋根） & G \\
\hline & 32 & 1951.2 .28 & 住宅 -3つの要素（気候・習慣・素材、勾配屋根） & G, H \\
\hline & 33 & - & 住宅の要素（習慣=ベランダが鍵） & $\mathrm{F}$ \\
\hline & 36 & - & ベランダの記述 (ベランダとフアサードの関係) & $\mathrm{F}$ \\
\hline & 37 & - & クラウストラ、3タイプの住宅 & $\mathrm{I}$ \\
\hline & 40 & 1951.3.19 & 既存の住宅のスケッチ（煙出、勾配屋根） & $\mathrm{H}$ \\
\hline W1-8 & 89 & 1951.3.24 & タージ・マハル・ホテルの客室（図 8) & I \\
\hline
\end{tabular}

スケッチブック名：

W1-2: Ahmedabad, Février 1951, 1951 India, $1^{\text {er }}$ carnet, Ronchamp

W1-5: Album punjab, simla, Chandigarh W1-8: Carnet nivola 1

ル・コルビュジエが注目した要素を、以下のように表記する。;

短冊状の敷地 $=\mathrm{A}$ 、前庭 $=\mathrm{B}$ 、塀 $=\mathrm{C}$ 、裏庭 $=\mathrm{D}$ 、寝室 $=\mathrm{E} 、$ ベランダ $=\mathrm{F} 、$ 方位 $=\mathrm{G} 、$

屋根形状 $=\mathrm{H}$ 、建具（跳㸚上げ戸、クラウストラ） $=\mathrm{I}$

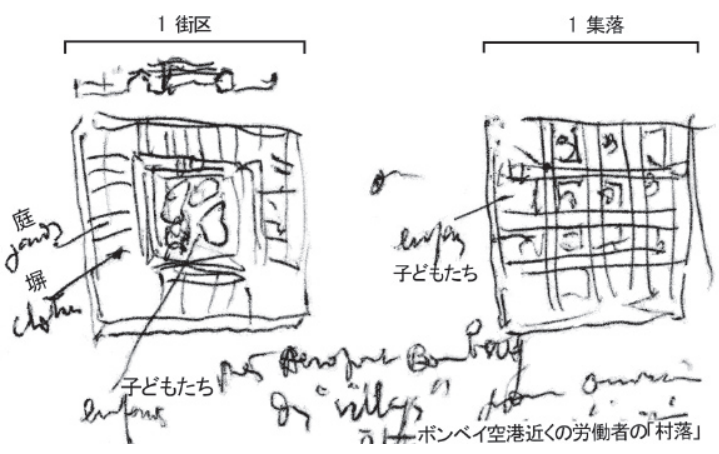

図 1 労働者の村落を描いたル・コルビュジェのスケッチ

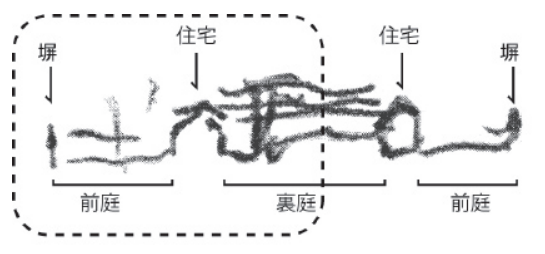

図 2 民家を描いたル・コルビュジエのスケッチ 


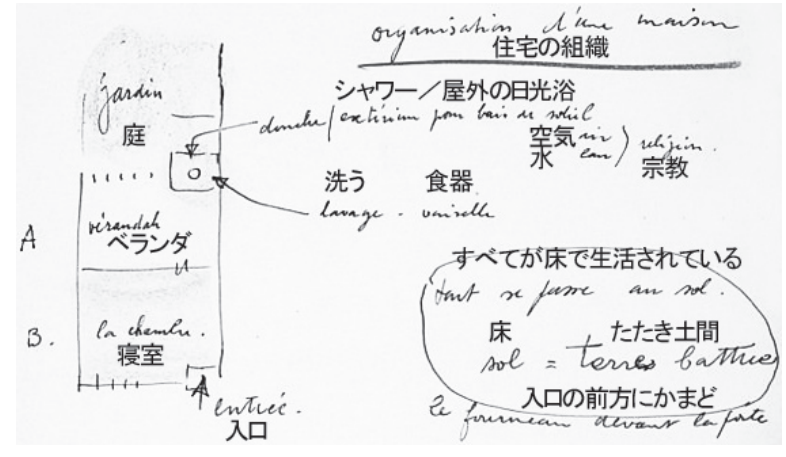

図 3 住宅平面構成を描いたル・コルビュジエのスケッチ

る。左図が 1 街区の平面図と断面図で、右図がその街区を縦横 4 つ ずつ組み合わせた集落の平面図である。

\section{3-1-1. 短冊状敷地}

左図の断面図を拡大したものが図 2 である。これを見ると、 1 戸 の住宅は片側を街路に接する間口が狭く奥に細長い短冊状の敷地に 建ち、「前庭」と「裏庭」を伴う。

\section{3-1-2. 前庭 $\cdot$ 塀 $\cdot$ 裏庭}

前庭は住宅が占める面積に比べて倍以上の広さがある。断面図を 見ると、街路との境界には塀が設けられ、この塀が両隣の住宅の前 庭とも隔てているため、前庭は周囲から閉じたプライベートスペー スになっている。

裏庭は、住宅の奥に広がる街区共有の庭である。個々の住宅の裏 庭が集められて一つの大きな庭を形成している。

平面図の表記を見ると、前庭は「庭(jardin)」であるが、裏庭は「子 どもたち(enfants)」と書かれ、樹木が描かれている。これは裏庭が

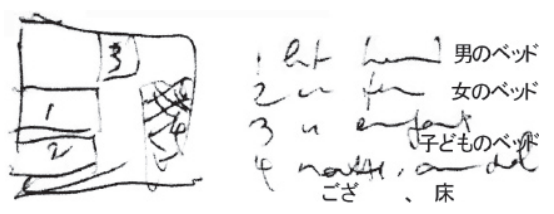

図 5 寝室を描いたル・コルビュジエのスケッチ

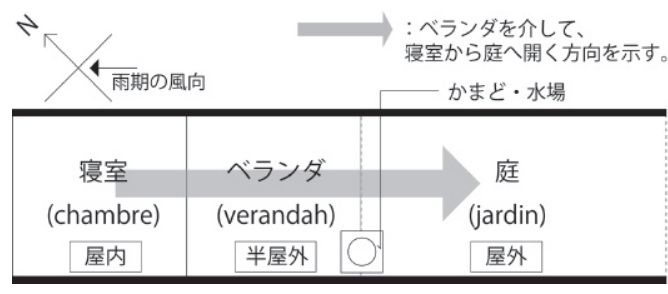

図 4 住宅平面の模式図

前庭とは異なる性格を有することを意味している。裏庭は一定の広 がりを有する樹木が林立した共有の広場で、子どもたちが自由に動 き回れる。

\section{3-2. 住宅平面構成}

住宅内部の平面構成は、図 3 に描かれている。「住宅の組織 (organisation d'une maison)」と題された 1 枚のスケッチに 1 つの 平面図が描かれている。さらに、その平面図に引き出し線で各室が 詳細に説明されている注20)

平面図によれば、土着の住宅は入口から「寝室(chambre)」「ベラ ンダ(verandah)」「庭(jardin)」の順に配置される。

屋内の寝室を抜けた半屋外のベランダは、食器を洗う水場・かま どが庭に股がって配置され、食事を作ったり、採ったり、食器を洗 ったりするための生活の場として機能する。さらに、その奥に屋外 のシャワースペースへと続く。このように土着の住宅は、屋内の寝 室から半屋外のベランダを介して、庭に開く構成を有している。こ れを模式図にすると、図 4 の通りである。

\section{3-2-1. 誛室}

戝 5 は図 3 の次頁に描かれたもので、寝室の平面図である。 寝室は矩形の 1 室空間で、両親と子供の 3 つベッドが配され、そ の向かいにござが敷かれている注21)。

\section{3-2-2. ベランダ}

図 6 は「家庭での生活(vie domestique)」と題された 1 枚のスケ ッチである。このスケッチには、ベランダの模式図とベランダで可 能な生活行為が描かれている。
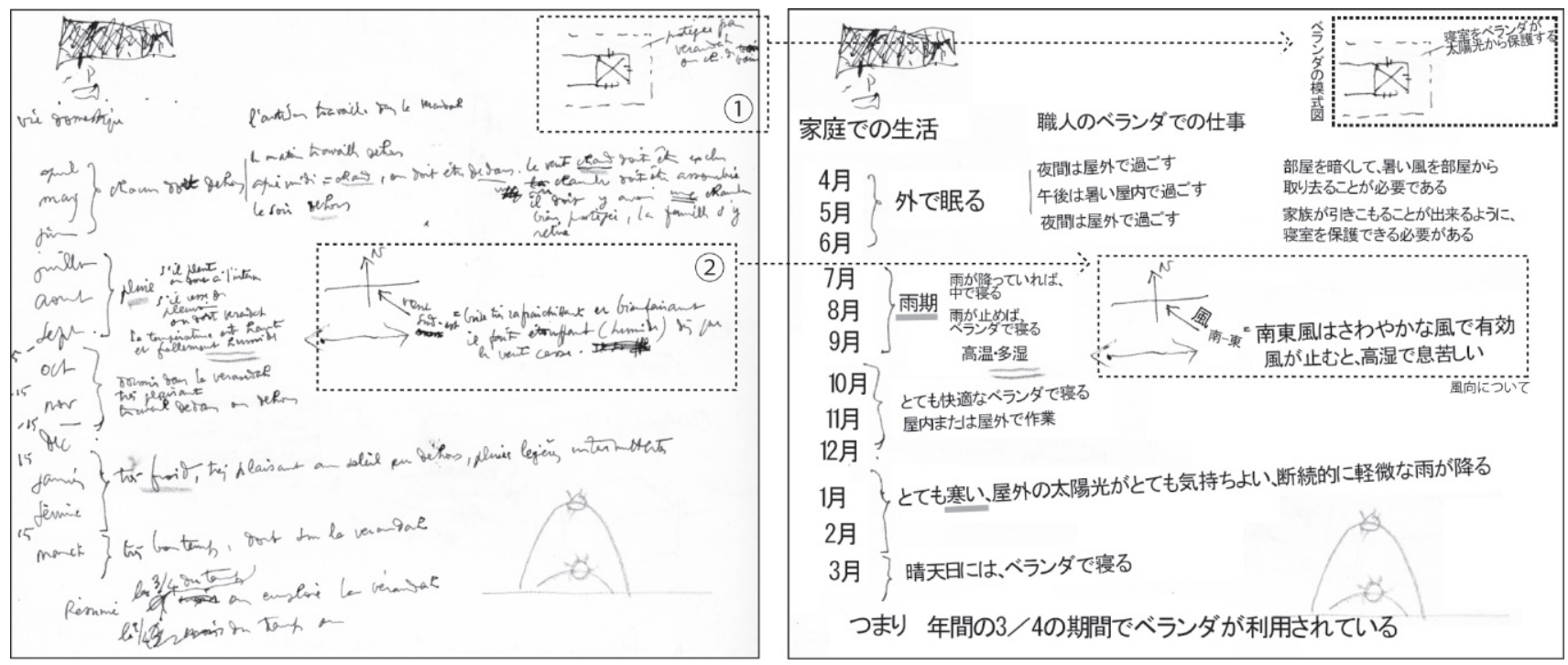

図 6 ル・コルビュジェが記録した、季節ごとの住宅での生活（左図：原図、右図：邦訳） 


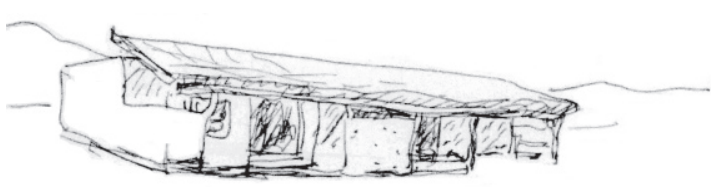

図 7 勾配屋根の民家を描いたル・コルビュジエのスケッチ

図 6 右上に描かれているベランダの模式図をみると、「ベランダ は太陽光から寝室を保護する注22)」と書き込まれている。ル・コルビ ユジエの捉えたベランダは軒下空間のことで、日射を遮ることが出 来るほど深い軒の下に広がる半屋外空間を指す（図 6-(1)参照)。

生活行為の記述に注目すると、 1 年間を 5 つに分けて記述されて いる。この内容は図 6 の右図の通りである。記述によれば、低気温 または降雨の場合を除く、「年間の $3 / 4$ の期間でベランダが利用され ている」。ベランダが、住宅の中でもとくに重要な土着の要素と捉え られていた。

\section{3-2-3. 方位}

図 6-(2)をみると、ル・コルビュジエは方位に注目し、高温多湿な 時期に「南東風のささやかな風で有効」であるとメモしている。高 温多湿になる雨期の不快な住環境を解消寸るために、雨期に吹く南 東風を取り入れて、寝室の熱・湿気を取り除くことが必要だと彼は 考えていたのである。

\section{3-3. 住宅を覆う片流れ屋根}

ル・コルビュジエが描いた住宅の屋根形状には、片流れ屋根が多 く含まれている。その 1 例を示すと、図 7 である。

図 7 に描き込まれた陰影を見ると、その屋根面は日照を遮るよう に勾配がつけられている。屋根は上方が開放されており、高温多湿 で室内に熱がこもる場合に、その熱が排出される仕組みになってい る。

また、深い軒の出によって、その下にひろがるベランダは日射を 避けて、外気に面した日陰のスペースとなる。

\section{3-4. 住空間に利用される建具-クラウストラと跳ね上げ戸}

図 8 は、ボンベイにあるタージ・マハル・ホテルの客室を描いた スケッチである注23)。1 枚に内観パース・平面図・断面図・断面詳細 図が描かれている。断面図と平面図を照らし合わせてみると、その 客室は、ベッドと水迴りがある寝室とベランダで構成されているこ とが分かる。

ル・コルビュジエは 2 つ建具に注目している。1つは、寝室と ベランダとを仕切る、跳ね上げ戸である。内観パースや断面図に描

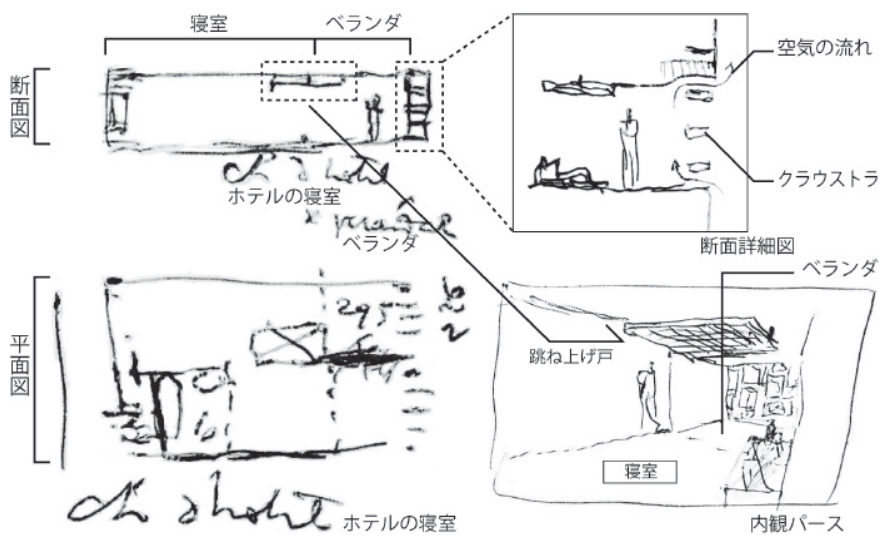

図 8 タージ・マハル・ホテルの客室を描いたル・コルビュジェのスケッチ

かれているように、戸を開けると寝室とベランダが一続きになって、 一体的に利用することができる。

もう 1 つは、ベランダと外部との境界に設けられている「クラウ ストラ(claustra)」である。これは日照を遮りながらも通風を確保す るために、隙間を空けて煉瓦を積んで造られる仕切り壁のことであ る。断面詳細図をみると、クラウストラは室内の空気を外気へと放 出し、外気を取り入れる換気装置としての役割を担っている。

\section{3-5. 小結}

以上のように「短冊状敷地」「前庭」「裏庭」「塀」「寝室」「ベラン ダ」「方位」「屋根形状」「建具」の 9 要素を拾い上げ、これらにル。 コルビュジェが着目した理由を考えてみると、彼にとっていかに高 温多湿な気候への対応が重要だったかが理解できよう。

とくにル・コルビュジエがスケッチと言説で詳述するのが住宅平 面構成である。すなわち、土着の住宅に見られる寝室・ベランダ・ 庭（前庭あるいは裏庭）の 3 要素とその関係に、彼は強い関心を示 しているのである。この 3 要素のなかでも、強い日差しを防ぎ、風 を取り入れる役割を担い、生活の中心的な場となる半戸外空間の心゙ ランダに対する彼の評価が高いように思われる。

細長い敷地上に直列に並ぶ室内・ベランダ・庭のあり方をル・コ ルビュジエがどれほど高く評価して、それを自らが新規に構想する 住宅計画に導入したかを、次章で、彼の「110 $\mathrm{m}^{2} の$ 廉価住宅」案の 分析を通して見てゆくことにしよう。

\section{4. 土着の要素を取り入れた住宅構想 〜「110 m廉価住宅」}

$110 \mathrm{~m}^{2}$ の廉価住宅でル・コルビュジエが目指したのは、土着的な 住宅構成と現代的な技術とを組み合わせて、地域特有の篇しい気候

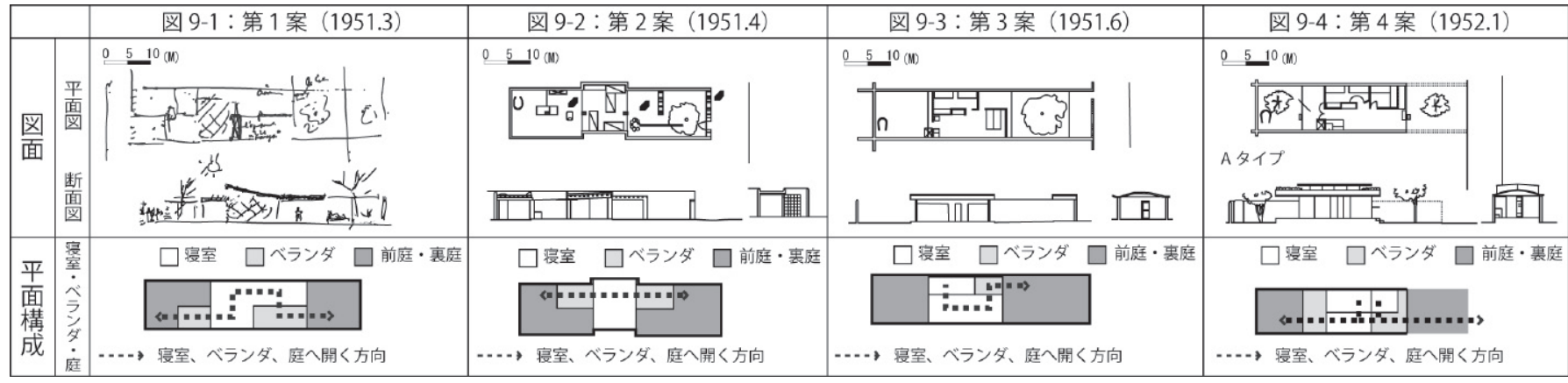

図 $9110 \mathrm{~m}^{2}$ の廉価住宅の計画図面と平面構成 


\begin{tabular}{|c|c|c|c|c|}
\hline & 図 10-1：第1案(1951.3) & 図 10-2：第 2 案 (1951.4) & 図 10-3：第 3 案 (1951.6) & 図 10-4：第 4案 (1952.1) \\
\hline 地 & 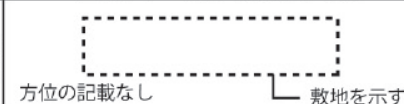 & 南 & 南 & 南 \\
\hline & 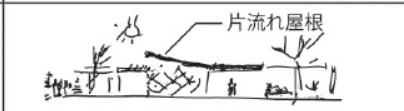 & 阹屋根 (上面 : 需植 & 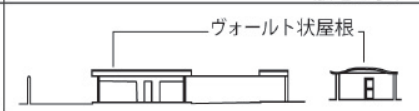 & 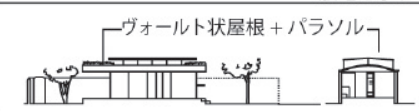 \\
\hline 种 & 来記載 & 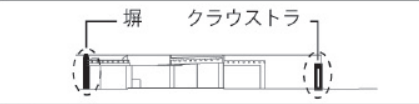 & 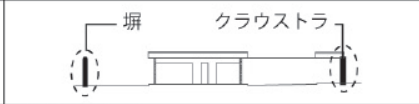 & 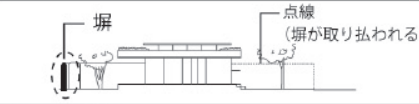 \\
\hline & & 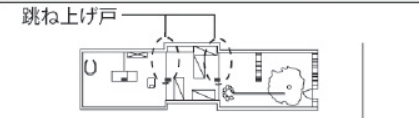 & クラウストラ & 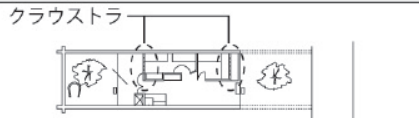 \\
\hline
\end{tabular}

図 $10110 \mathrm{~m}^{2}$ の廉価住宅に見られる土着的な要素「敷地」「屋根」「塀」「建具」

や環境に適合した廉価住宅を設計することであった。設計過程での 同案の変容を追うことによって、彼の設計思考がどれほど土着的要 素に傾くものであったかを明らかにする。

$110 \mathrm{~m}^{2}$ の廉価住宅に関する図面を整理すると、第 1 案(1951 年 3 月)・第 2 案(1951 年 4 月)・第 3 案(1951 年 6 月)・第 4 案(1952 年 1 月)の 4 つになる。第 1 案・第 2 案はル・コルビュジエが抽出した土 着の要素の組み合わせで構成されている。だが第 3 案では、同時期 にボゴタで確立された手法を取り入れて、それと土着の要素とを融 合させている。この時点で主要な骨格は固まり、第 4 案では土着の 要素のほうを更に展開させている。この過程を、さらに詳しく分析 することにしたい。

\section{4-1. $110 \mathrm{~m}^{2}$ の廉価住宅を構成する要素}

$110 \mathrm{~m}^{2}$ の廉価住宅を構成するのは、前章でみた土着の住宅と同じ 「短冊状敷地」「寝室」「ベランダ」「前庭」「裏庭」「方位」「塀」「屋 根形状」「建具」の 9 要素だと考えてよいであろう。簡単に内容を説 明すると、次のようになる（図 9、10参照）。

「短冊状敷地」は、片側が街路に面し間口が狭く奥に細長い短冊 状の敷地である。この敷地形状は、すべての案に共通する。

「寝室」は敷地の中央に配される屋内空間であって、就寝のため のスペースとキッチンで構成されるが、第 2 案だけは多少異なる。

「ベランダ」は一面以上が外気に面する半屋外で、寝室の両側に 設けられる。第 3 案だけ、一方にの夕設けられている。

ベランダに続いて街路側に「前庭」、敷地の奥に「裹庭」が配され る。すべての案を通じて、前庭と裏庭が設けられるが、各案でその 用途に違いがある。

以上の「敷地」「寝室」「ベランダ」「前庭」「裏庭」の 5 要素で 110 $\mathrm{m}^{2}$ の廉価住宅の平面は寝室を中心に、ベランダ、庭へと構成されて いる (図 9 参照)。

「方位」は、敷地の向きに表れている。第 1 案には記載されてい ないが、第 2 案以降はすべての住宅の敷地の奥行き方向を北西-南東 軸に向けている。これは前章の図 6-(2)で注目した南東風を取り入れ るためと考えられる。

「塀」は前庭と裏庭に、寝室側を除く 3 辺を囲むように設けられ る。塀が隣家や街路に対する目隠しとなって、庭は屋外のプライベ ートスペースとして利用される。最終案では、前庭側の塀が取り払 われている。

「建具」は、寝室と外部を仕切るものである。第 1 案ではその詳
細が読み取れないが、第 2 案以降は読み取り可能である。建具によ って、人の動きのみならず通風や日照もコントロールされる。

「屋根形状」は、設計段階でル・コルビュジエがもっとも力を入 れた要素で、通風、雨水処理と利用、日照の寸べてと大きく関係し ている。ゆえに、すべての案で変更され改良されている。屋根形状 には、片流れ屋根、小梁が露出したルーバー状屋根、陸屋根、ヴォ ールト状屋根の 4 つがある。

これから、以上の 9 要素を詳しく見たいが、紙面の都合上、前案 との間で変更が加えられた要素のみを分析の対象とする。

\section{4-2. 第 1 案 (1951 年 3 月 28 日付のラフスケッチ)}

第 1 案は、1951年 3 月 28 日付の、ル・コルビュジエが描いた 2 枚のラフスケッチである注 ${ }^{24)}$ ここのスケッチで注目したいのは平面 図・断面図・屋根伏せ図で、各々 1 づ゙つあ (図 11 参照)。

平面図によれば、寝室は L 字型で、就寝のためのスペースとキッ チンから構成される。就寝のためのスペースとキッチンはそれぞれ 別の庭に面し、キッチン側は間口の半分ほどをベランダとして切り 欠かれている。就寝のためのスペース・キッチンは、それぞれの延 長となる半屋外のベランダに続く。

ベランダは 2 つって、寝室の両側に配されている。1つはキッ

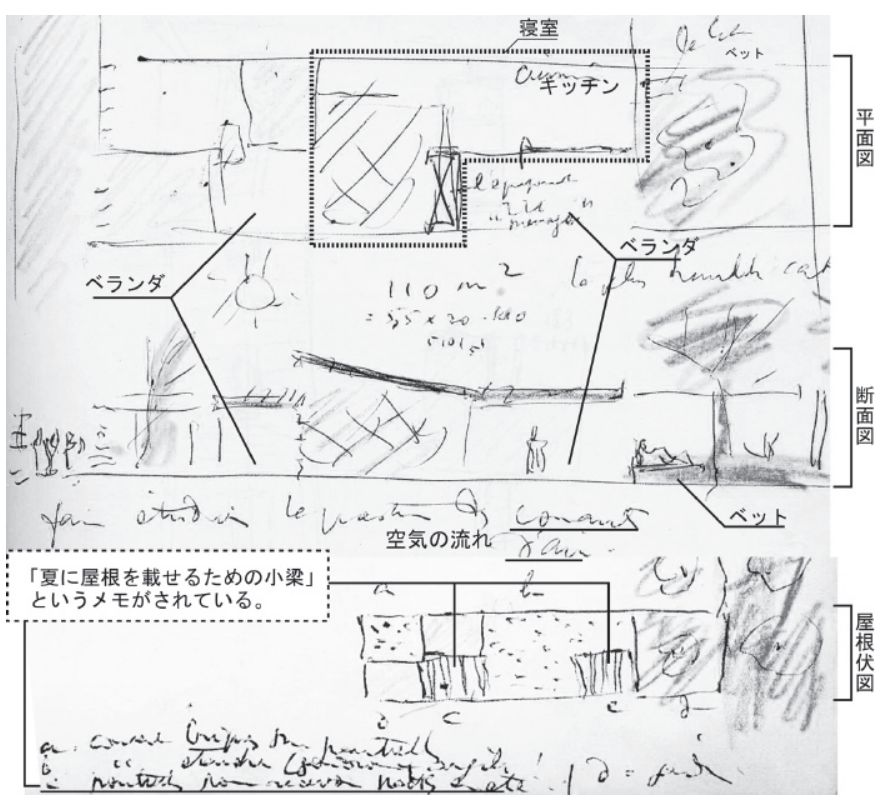

図 111951 年 3 月 28 日付のラフスケッチから一部拔粋 


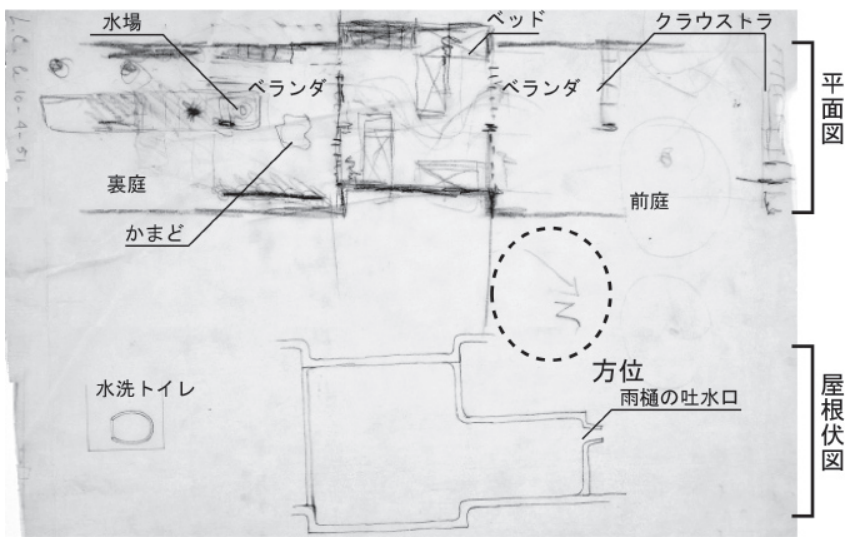

図 121951 年 4 月 10 日付のル・コルビュジエのラフスケッチ

チン横にあり、もう 1 つは就寝のためのスペースに接して間口半分 ほどの幅で、庭に向かって突き出す。これらのベランダは、その延 長となる屋外の庭につながっている。

前庭・裏庭も寝室の両側にあり、各々用途が異なる注25)。キッチン 側の庭には樹木が植えられ、その下にベッドが置かれて、「寛ぎの庭」 として利用される。就寝のためのスペース側の庭は、水洗便所があ る「サービス用の庭」である。このように、屋内の寝室からべラン ダ、そして庭と一続きの空間となり、生活を外部へと拡げる構成に なっている。

屋内・半屋外での生活に対応して屋根形状が異なる。寝室はレン ガ造の陸屋根だが、就寝のためのスペース部分だけは上部に開口の ある片流れ屋根になっている。日照を遮る一方、寝室に溜まった高 温多湿な空気を開口から排出する仕組みである。

両側のベランダに掛かる屋根は、小梁が露出したルーバー状屋根 である。「夏に屋根を載せるための小梁注 26)」と書き込まれているよ うに、夏場の対策として、仮設に屋根を載せて日射・雨を防ぐ仕組 みになっている。通常はルーバー状の屋根が日照を遮り、ベランダ は外気に開かれた半屋外空間として機能する。

\section{4-3. 第 2 案 (1951 年 4 月 10 日付のラフスケッチ)}

第 1 案を具体的に検討したものが、第 2 案である。1951 年 4 月 10 日に、ル・コルビュジエが平面図と屋根伏図を 1 枚のラフスケッ チとして描いた（図 12 参照）。このスケッチに基づいて、所員の A.メゾニエ (André Maisonnier) が提出図面として清書した（図 13 参照)。

第 2 案も第 1 案と同様に、寝室からベランダ、そして庭に続く構 成になっている。だが、キッチンが、かまどと水場として裏庭側の ベランダに移されたために、平面形状にわずかな変更が生じている。

寝室は、キッチン分だけ規模が縮小され、4 ベッドが置かれた方 形となった。この寝室に接して、ベランダが前庭と裏庭の両側に間 口の半分ほど突き出して設けられている注27。そして、両ベランダの 外に、前庭が寛ぎの庭として、裏庭がサービス用の庭として配され ている注28)。裏庭側ベランダのかまど・水場と関連して、裏庭自体も ユーティリティ・スペースとして機能する。このように寝室、かま どや水場を備えた裏庭側のベランダ、そしてサービス用の庭へと続 く構成は、ル・コルビュジエが捉えた土着の住宅平面を継承するも のである。裏庭側のみならず前庭側にも、その土着の構成が採用さ れている (図 9-2 参照)。

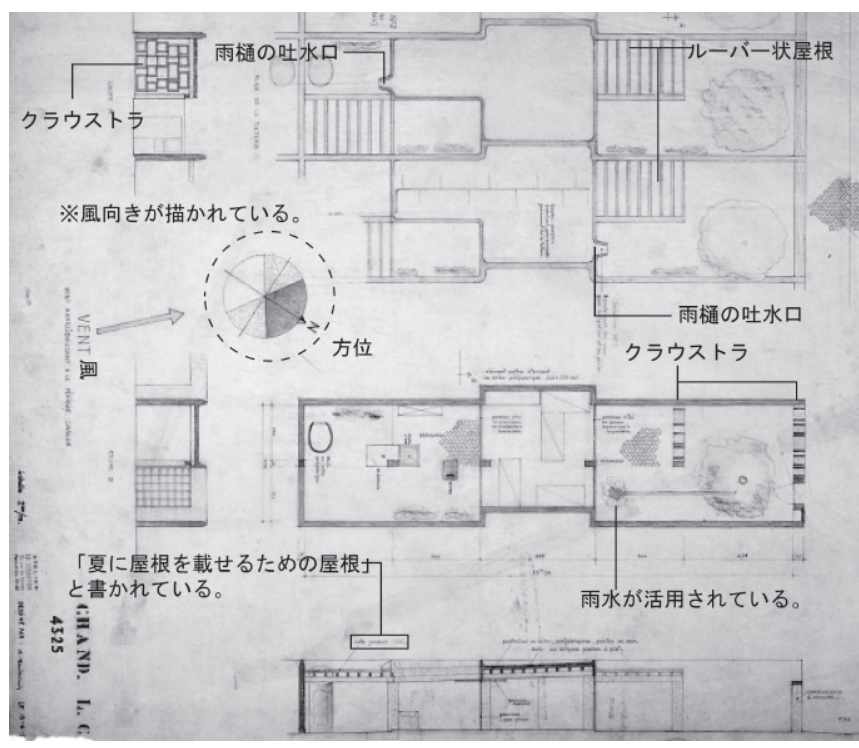

図 13 ル・コルビュジェのラフスケッチに基づいて描かれた提出図面

建具・塀にも、住宅内部での生活を快適にするための工夫が見ら れる。まず寝室と両側のベランダとを仕切る建具に、タージ・マハ ル・ホテルで見られたような跳ね上げ戸が用いられている。この戸 を開放すると、ベランダと寝室は一続きの空間となり、通風も確保 できる注29)。

寝室を前庭に対して開放するために、プライバシーを確保できる 塀が設けられ、街路との境界に設けられる塀をクラウストラとして いる。さらに前庭とベランダの間にも、クラウストラを設けること によって、2 重の目隠し効果をもたせている。これによって寝室か ら前庭に向かって生活を拡げ、それが同時に、通風の確保にもつな がっている。

この地域では、通風だけでなく雨水処理が大きな課題で、雨水で 屋内や半屋外の生活が务かされる恐れがある。屋根形状は片流れ屋 根から陸屋根に変更され、屋根上面に雨樋が設置された（図 $12 、 13$ 参照)。前庭側のベランダは第 1 案と同じくルーバー状屋根だが、生 活の場となる裏庭側のベランダの上には陸屋根が延長されている。 屋根上面に設けられる雨樋の吐水口の位置は、前庭側と裏庭側の 2 パターンがあり、前庭では雨水が活用されている注30)。

ル・コルビュジエが現地調査で見出した土着の要素は、平面構成 のみならず塀や建具なども、この住宅設計に活かされ計画されてい る。屋根形状は片流れ屋根ではなくなったが、地域の気候により適 した住宅へと設計変更が加えられたと考えられる。

\section{4-4. 第3 案(1951 年 6 月 14 日付の図面)}

第 3 案は、1951 年 6 月 14 日付の図面である (図 14 参照)。 1 枚 の図面に、 1 平面図と 2 断面図がセットで、上下に描かれている。 上はボゴタ都市計画でのル・コルビュジエの協働者、ホセ・ルイ・ セルト (José Luis Sert, 1902-1983) が、ボゴタでほぼ同時期に計 画した住宅案であり、下はル・コルビュジエがチャンディガールで 提案する住宅である注311。

比較すると、ル・コルビュジエがセルト案から影響を受けたと思 われる要素が 2 つある。 1 つは個室を用いる平面構成、もう 1 つは 屋根形状である (図 15 参照)。 


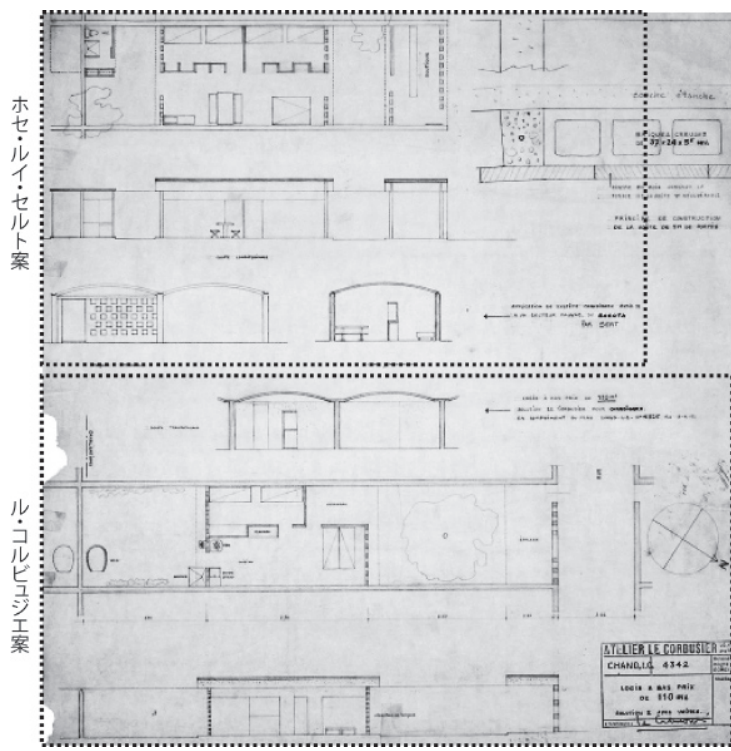

図 14 1951年 6 月 14 日付の図面(FLC51614)

まず平面構成では、セルト案は、キッチン・食卓と一体になった 両親の部屋と、男の子と女の子の部屋をそれぞれ設けている注32)。前 庭と裏庭があるが、ベランダはない。一方、ル・コルビュジエ案で は、男の子と女の子に分けず子供部屋を 1 つにまとめて規模を縮小 し、余った空間をベランダにしている。前庭と裏庭はセルト案の倍 以上に拡大されている。そのベランダに面するのが前庭（寛ぎの庭） である。このように個室が現れても、子供部屋から、そして食卓・ キッチンと一体となった両親の部屋からベランダに出て、さらに半 屋外のベランダから寛ぎの庭へと続く土着的な構成が、基本的に維 持されているのである（図 9-3 参照）。

次に屋根形状に関しては、これまでの前 2 案でも、通風・日照・ 雨水への対応として、土着的な屋根形状をベースに改善が加えられ てきた。だが、ここでル・コルビュジエはセルト案に似たヴォール 卜状屋根へと大きく変更している。

図面に添えて書かれた同じ日付の書簡に次のような説明がある。

$「$ (上図の) 住宅は、セルトの指揮下で、1951 年 5 月にボゴタで計画さ れた。これはメデリンとボゴタで実現した案で、低い广亡チのヴォンルト 状屋根を $5 \mathrm{~m}$ 久 が要らない工法を採用する。 $5 \mathrm{~m}$ のヴォールト状屋根が覆うその下には、高 さ $1.83 \mathrm{~m}$ の仕切り棚で分割された幾つかの部屋がある。空気、空間、それ らの流れが、寸心゙ての部屋を通り抜ける。小さな住宅の両端は、煉瓦で造 られたクラウストラで構成する。」(傍点筆者) 注33)

そのヴォールト状屋根はレンガとモルタル(béton)で造られた簡 易なものだが、それでも「低いアーチ」で「5m スパン」の無柱の

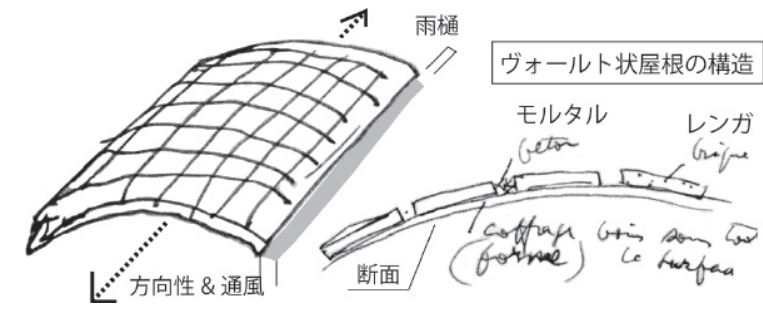

図 16 ヴォールト状屋根の構造とその特徵

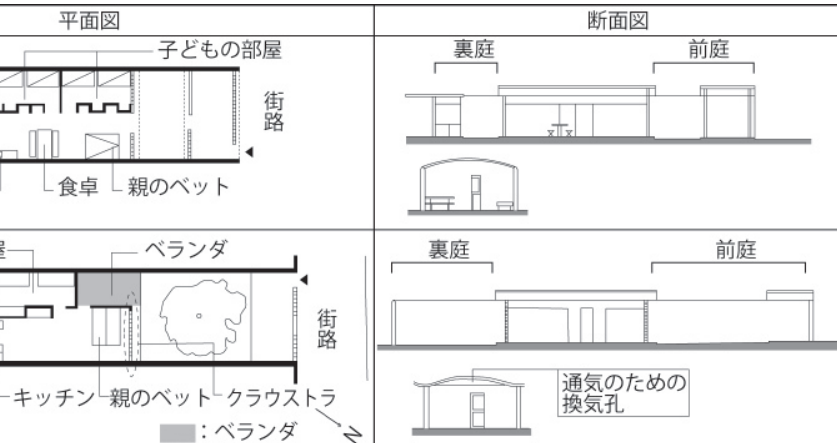

図 15 セルト案とル・コルビュジエ案の比較

室内空間を生み出すことができることをセルトから聞いて、ル・コ ルビュジェは、このアイデアを採用したのである。

そして、ヴォールト状屋根の中央部のむくりと高さ $1.83 \mathrm{~m}$ の仕切 り棚との間の隙間を利用して通気スペースをとっている（図 15 右 下参照)。さらに、寝室と庭との境界をクラウストラにすることによ って (図 15 左下参照)、空気の流れのある一体的な室内空間という 彼の当初からの住宅構想を維持している。しかも図 16 に示すよう に、(ヴォールト状) 屋根の軸を細長い住宅空間そのものの軸と重ね ることによって、ベランダ・庭へと展開する構成をさらに強化して いる。また、屋根上部に雨樋を付設していたが、ヴオ一ルトを支え る支持壁上面を雨樋とする変更によって、より効率的に雨水が排せ るようになった。

この住宅案で使われる塀（クラウストラ）に前案からの変化はな いが、屋内と外部を仕切る建具もクラウストラのみで、跳水上げ戸 は使われなくなっている（図 10-3 参照）。

\section{4-5. 第 4 案 (1952 年 1 月 18 日付の図面)}

第 3 案で計画の骨格が、ほぼ決定したと考えてよいであろう。そ れに部分的改良を加えたのが第 4 案である。ル・コルビュジエの署 名が添えられた 1952 年 1 月 18 日付の図面である注34。

この住宅には $\mathrm{A}$ タイプと Bタイプの 2 つがあって、方位、平面図、 2 面の断面図を描く図面が、それぞれにある。両者を比較すると、 間口・奥行きの寸法に違いはあるが、同じ構成になっている。

ベランダを生活の中心とし、屋内からベランダを介して庭に生活 を広げる土着の住宅構成が、前庭側だけでなく裏庭側にも適用され ている（図 9-4 参照）

平面構成をみると、両親の部屋も個室化され、子どもの部屋と前 後に並んで片側に配されている。もう一方側にキッチンが置かれて いる。前庭側のみだったベランダが裏庭側にも付設され、ベランダ とキッチンが一続きの空間となり、一体的な生活の場となっている (図 17 参照) 注35)。その裏庭は樹木が植えられ、静かで光溢れるプ ライベートな寛ぎの庭である。他方、前庭については街路との間の 塀が取り払われ、街路に面して並ぶ前庭が、街路と一体的に利用で きる半公共的空間として開放されている。

屋根形状に前案からの変更はないが、さらに屋根自体の蓄熱を避 ける改良が加えられている。例えば、「パラソル(parasol)」と命名 された薄い屋根でヴォールト状屋根を覆い、二重屋根とする。これ によって、ヴォールト状屋根とパラソルとの間に通風が確保され、 さらに、日射が当たりやすいヴォールト状屋根の両端に植栽 


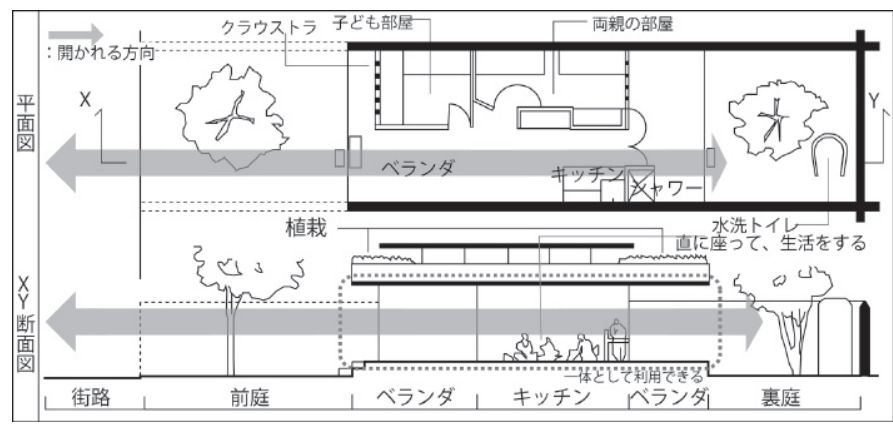

図 17 第 4 案（A タイプ）の平面・断面構成に見る一体的な生活の場

(roseax) を設けている (図 17、断面図参照)。

\section{4-6. 小結}

以上、変遷を辿ったように、ル・コルビュジエの住宅構想には、 計画期間 2 年で第 1 案から第 4 案まであって、本章では、何が変わ り、何が変わらなかったかを明らかにした。分析に当たっては、第 3 章でル・コルビュジエが土着の集落・住宅の調查から抽出した 9 つの要素に着目した。短冊状敷地・塀・前庭・裏庭・寝室・ベラン ダ・方位・屋根形状・建具である。

「キッチン・食卓」「個室（両親の部屋、子供の部屋）」といった 新しい要素も加わるが、元々の土着の 9 要素に着目することで、ル・ コルビュジエが新たに住宅を構想するときにも、強い日射、雨期の 高温多湿、多い降水量、南東風といった地域特有の気候がもたらす 条件に、いかに土着の住宅を参照しながら対応したかを、具体的に 明らかにできたと思われる。

第 3 案では、個室が現れるが、その個室をベランダにつなぎ、さ らにベランダを庭と一体化することによって、高温多湿な部屋に閉 じ込められる生活からの開放を果たしている。屋根形状が大きく変 わっても、室内を自然の風が吹き抜ける状態を維持したり、効率良 く雨水を排除したり寸る工夫も忘れていない。寛ぎの庭の考え方も 最後まで保持されている。

第 1 案・第 2 案では、土着の集落・住宅の調査で着目するように なった伝統的要素を直接引用する形で住宅設計が進んだが、第 $3 、 4$ 案になると、近代的な平面計画・構造の考え方も導入されるように なる。それによって、屋根形状のように大きく変更される要素もあ るが、4 案の分析によって、ル・コルビュジエがいかに土着の要素 を尊重しつつ限定的に新たな考え方・技術を導入したかを解明でき たように思われるのである。

\section{5.まとめ}

ル・コルビュジエはチャンディガール州都計画に参画するに当た って、現地調查をし、土着的な要素を記録していった。記録内容は 多岐にわたるが、多くが住宅の土着的な要素に関するものだった。 なかでも記録が詳細なのは住宅平面構成である。強い日射と夜間 も変わらない高温多湿という厳しい気候の下でも、快適な生活を送 ることができる半屋外のベランダの工夫を、彼は高く評価し、ベラ ンダを介して寝室を屋外の庭に開く構成に注目している。

そして、ル・コルビュジエは、チャンディガール州都計画に関連 する、低所得者のための簡易で廉価な住宅 (「110 $\mathrm{m}^{2} の$ 廉価住宅」)
の構想に、土着の要素とその構成の継承を積極的に試みたのである。

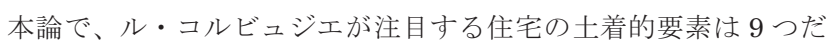
ったことを明らかにした。これらの要素を組み合わせて、この地域 では、簡素で、かつ低廉な価格で快適な住環境がつくり出されてい たのである。このことは、新しく誕生する都市を構成する住宅「110 $\mathrm{m}^{2}$ の廉価住宅」を考える際にも、きわめて重要な要件となった。

$「 110 \mathrm{~m}^{2}$ の廉価住宅」は 2 年間に 4 案がつくられているが、変化 を辿ってみると、ル・コルビュジエが土着の要素を尊重しつつ限定 的に新たな考え方・技術を導入して、いかに新都市にふさわしい住 宅を構想していったかが、具体的に浮かび上がってきた。

ボゴタの場合もチャンディガールの場合も、ル・コルビュジエが 構想する住宅は、低所得層が少なくない大勢の市民が住む都市の構 成単位となるものだったことを忘れてはならないが、それが簡易で、 低廉で、それでも快適で質の高いものであるために、彼が現地の既 存集落・住宅を調查して瑗しい気候風土への対応から生夕出された 土着の要素を抽出し、可能な限りそれらの要素を設計に活かそうと 努めていたことが、本論によって明らかにされたと考える。

注

※ル・コルビュジエ財団に保管・管理される文書資料はFLC, 整理番号, ページ と、また図面はFLC 登録番号と表記する。

注1）拙稿：ボゴタ都市計画におけるル・コルビュジエの低層住居街区に関す る研究 一地域的な要素くクアドラ〉に基づいた計画手法, 日本建築学会計 画系論文集，No.650，pp.955-961，2010.4 参照

注2）ル・コルビュジエのボゴタ都市計画の参画期間は 1949年 8 月 51年 5 月 までである。拙稿：ル・コルビュジエのボゴタ都市計画における計画時期 について, 日本建築学会大会学術講演梗概集, F-2, pp. 131-132, 2009

注3）インドの初代首相ジャワハルラール・ネルー(Jawaharlal Nehru, 1889-1964, 在任1947-64)の「過去の伝統の足かせにとらわれない、インドの自由の象 徵を表寸新都市」構想のもと、計画がスタートした。新州都はヒマラヤ山 脈の麓(高度 $400 \mathrm{~m}$ )、2つの川に挟まれた平地に位置する。

注4）想定人口は 15 万人。計画のコンセプト、敷地の選定、敷地調査、前任の プランナーによるマスタープラン作成がすでに完了しているため、それを 引き継いで、計画の実現を果たすことが求められていた。

注5) $110 \mathrm{~m}^{2}$ の廉価住宅と、この住宅が集合して形成される「750人のための村 (les villages de 750 habitants)」は、このときル・コルビュジエが提示し た3つの計画案の 1 つである。FLC, P2-17-177参照

注6）ル・コルビュジエはこの住宅を協働者たちが参考にす心゙き具体的なモデ ルとして計画した。「この都市すべての建設で、もっとも慎ましい家から宮 殿までの寸心゙ての基準となる平面図と断面図」と彼は述べ、その計画意図 を「気候グリッド(grille climatique)」という形で協働者たちに提示した。 FLC, P2-17-177参照

注7）ル・コルビュジエは自身の案を実現させるべく協衔者たちを説得した。 さらに、彼はネルーに㗢きかけ、ネルーから協働者たちへの説得を手助け してもらった。だが、協働者たちの合意が得られず、ル・コルビュジエの 住宅案がそのまま採用されることはなかった。FLC, P2-8-41-42

注8) $110 \mathrm{~m}^{2}$ の廉価住宅案は、協働者たちが計画・建設する州政府所有の、低 賃料の賃貸住宅の基礎となっている。この住宅案と協働者たちが計画した 住宅案(参考文献2、6参照)を見比べると、類似点がいくつも見受けられる。

注9）紙面の都合上、本論でサラバイ邸などとの関連性について十分に述べる ことは出来ないが、この廉価住宅と同様に、厳しい気候・環境に対応する ために土着の要素が参照された計画であることが強く伺えるのである。

注10） FLC, P2-8-41-42 1952年4月4日付のネルーの署名がある書簡

注11） $110 \mathrm{~m}^{2}$ の廉価住宅に関寸る図面・スケッチは、参考文献1、3、4 参照 している。ル・コルビュジエ自身が作成したものと、それをもとに所員が 製図したもののいずれかに判別可能な図面を分析対象とした。

注12) FLC,W1-5-1-55 1951年2月 23 日〜 51年3月19日の記録。インド北部を 中心とした調査記録。伝統的な住宅のスケッチ、州都計画の全体構想、キ ヤピトル・コンプレックス計画から住宅計画まで、内容は多岐にわたる。

注13) FLC, W1-8参照 
注14) FLC,W1-2、参考文献1を参照。

注15) FLC,P2-11,136; 'Selection of Architects \& Town Planner for Chandigarh Capital Visit of P. N. Thaper and P.L. Verma to Europe' (City Museum, Chandigarh), Reunion du 6 Decembre 1950, p.116

注16）ル・コルビュジエの現地訪問は、1964年4月を最後に、13年間で計23回。

注17）ネルー首相やアーメダバード市長サラバイ(Sarabhai)との会談や自動車 会社タタ(Tata)などの訪問のため、主要都市を迴っていた。

注18）ル・コルビュジエは、スコールへの対応として雨水処理・利用あるい は排水路の整備にも関心を示している。表1には表れていないが、スケッチ の中で彼は排水路を計画している。土着の住宅や集落に参照す心゙きものは 見られなかったが、現地調査の時点ですでに排水路が必要だと考えていた と言えよう。 FLC, W1-5-25参照

注19）「アスベストボードで造られた建物が集まって、幾何学的な形状の村 落が形成される。悪くない」とメモされている。FLC, W1-2-400参照

注20）FLC, W1-5-19, FLC05485C この平面図には次のように書かれている。 「A：ベランダ<倉庫と組織 料理、血をしまっておいたり、洗ったり= ベランダの標準的な組織>」。

注21）前頁に記載されたベッドのアクソメ図によれば、ベッドの1床は幅 $90 \mathrm{~cm} \times$ 長さ $198 \mathrm{~cm}$ である。この寸法から寝室は、12 13八ィート四方の大 きさであると分かる。

注22) FLC,W1-5-18、FLC05485A

注23） FLC,W1-8-89 1951年3月24日付のル・コルビュジェのスケッチ

注24）1枚目のスケッチには、廉価住宅の平面図・断面図・天井伏せ図・内観 パースが各々 1 つずつと、「750人のための村」の外観パースが 1 つある。 2 枚目には、廉価住宅の天井伏せ図と平面図が各々 1 つずつ、間口を長手方 向に2分する位置に設置される仕切り棚の断面図とパースが1つずつある。 FLC,W1-8-101と FLC,W1-8-103を参照。

注25）図面をみると、この住宅は両側に庭を有するが、そのいずれ側を前庭 とし、いずれ側を裏庭にするかは決定されておらず、前後を反転させた案 も同時に計画されている。これは水洗便所などの排水路が関係している。 この住宅で形成される住宅地全体の配置図を見ると、排水路を街路側に流 寸か、住宅の奥に流すか、で2通り検討されている。FLC,W1-8-100-101参照 注26) W1-8-101 第 1 案のスケッチの屋根伏図の説明を参照。

注27）寝室の両側に設けられたベランダはレンガで舗装されている。

注28）裏庭中央部の水場の隣りにシャワーが配され、水洗便所は裏の住宅と を隔てる壁際に設けられている。

注29）住宅内部でも、隣家にずれ込んで出来た凹みに家具を収納することで、 通風を妨げる障害を取り除く配慮がなされている。

注30）吐口を前庭側に設ける場合には、雨水を水盤で受け樹木に水をやる灌 溉システムが計画され、雨水が利用される。吐口が裏庭側の場合は、シャ ワーの所で排水する。

注31）図面上では両者の案に、街路に面して前庭に店舗が設けられているが、 ル・コルビュジエによればバリエーションを増やすためのもので、必ず備 えるというものではない。FLC,P1-16-223参照

注32）ル・コルビュジエの書簡によれば、男の子と女の子の部屋を分けて個 室にするセルト案の平面構成は、宗教上の理由であったことが説明されて いる。FLC,P1-16-222、参考文献5を参照。

注33）1951年6月4日付のピエール・ジャンヌレ (Pierre Jeanneret, 1896-1967) 宛ての書簡。ル・コルビュジェの協働者の一人であったホセ・ルイ・セル トは、現地でその任務を負っていた。FLC, P1-16-222

注34）所員のドーシによって描かれたもので、ル・コルビュジェの署名が添 えられている。AタイプはFLC29084、BタイプはFLC29082を参照。

注35）寝室とベランダの床は、地面との段差を $53 \mathrm{~cm}$ 程度設けて、床に直に座 って生活できる計画になっている。

\section{参考文献}

1) Le Corbusier Sketchbooks, Volume2 1950-54, MIT Press, 1982

2) Marg, Chandigarh, Vol. X V No.1, Bombay, December 1961

3) Le Corbusier plans 1950-1951, 第 3 集 DVD 第 11 巻, Echelle-1, Fondation Le Corbusier, Codeximages international, 2006

4) Le Corbusier Archive $X$, Garland Publishing, Inc. and Fondation Le Corbusier, New York, London, Paris, 1983

5) Josep m. rovira : José Luis Sert -1901-1983-, Leonora Saavedra (translation), Electra Architecture, 2003

6) Kiran Joshi: Documenting Chandigarh, Chandigarh College of Architec ture, 1999

\section{図版出典}

図 1、2. FLC, W1-2-400（筆者が加筆） 図 3. FLC, W1-5-19（邦訳：筆者）

図 4. 筆者作成図 5. FLC, W1-5-20（邦訳：筆者）

図 6. FLC, W1-5-18、FLC5485A（邦訳：筆者)

図 7. FLC, W1-5-17 図 8. FLC, W1-8-89 老一部抜粋（筆者が加筆）

図 9、10.FLC,W1-8-101、FLC29091、FLC05989、FLC05990をもとに筆 者作成

図 11. FLC,W1-8-101 を一部抜粋（筆者が加筆）

図 12. FLC06066 (筆者が加筆) 図 13. FLC29091 (筆者が加筆)

図 14. FLC05989（筆者が加筆） 図 15. FLC05989 より筆者作成

図 16. FLC, W1-8-105 より一部抜粋

図 17. FLC05990をもとに筆者作成

（2011年 5 月10日原稿受理，2011年 9 月26日採用決定） 